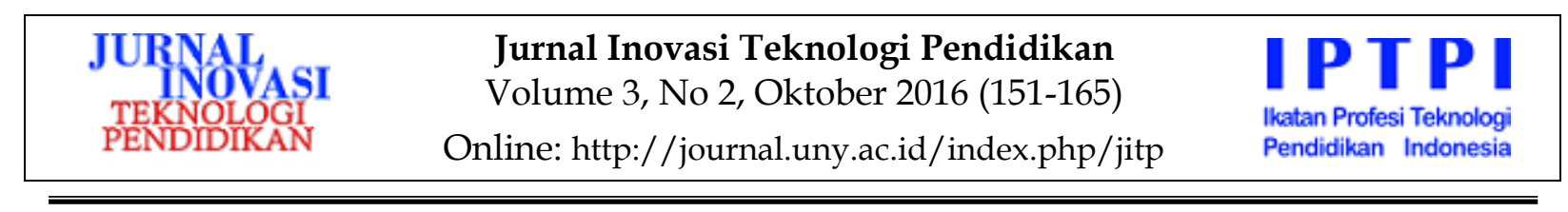

\title{
PENGEMBANGAN BAHAN AJAR BERBASIS WEB BERDASARKAN GAYA BELAJAR SISWA UNTUK MATA PELAJARAN FISIKA
}

\author{
Ary Purmadi, Herman Dwi Surjono \\ FIP IKIP Mataram, FT Universitas Negeri Yogyakarta \\ arypurmadi@uny.ac.id, hermansurjono@uny.ac.id
}

\begin{abstract}
Abstrak
Penelitian ini bertujuan menghasilkan bahan ajar berbasis web berdasarkan gaya belajar siswa, mengetahui kelayakan produk bahan ajar berbasis web,dan mengetahui efektivitas bahan ajar berbasis web pada mata pelajaran fisika di SMAN 1 Sukamulia. Model penelitian dan pengembangan ini dilakukan melalui tiga tahap, yaitu perencanaan, desain dan pengembangan. Proses validasi terhadap produk dilakukan dengan tahap uji alpha, uji beta dan uji coba produk. Hasil penelitian menunjukkan bahwa: (1) Bahan ajar berbasis web memiliki 5 fitur pembelajaran; (2) produk yang dikembangkan telah layak untuk digunakan (3) hasil tes gaya belajar siswa menunjukkan terdapat 14 pebelajar kinestetik, 9 pebelajar visual dan 8 pebelajar auditori; (4) terjadi peningkatan pencapaian hasil belajar siswa setelah menggunakan bahan ajar berbasis web sebesar $31,87 \%$. Nilai rata-rata pretest 52,03 , dan postest 83,90. Persentase ketuntasan belajar siswa 97\% (30 dari 31 siswa), dan penilaian respon siswa saat menggunakan menunjukkan kategori baik. Dari hasil penelitian tersebut, dapat disimpulkan bahwa pembelajaran dengan menggunakan bahan ajar berbasis web telah efektif.
\end{abstract}

Kata kunci: bahan ajar berbasis web, pengembangan, gaya belajar

\section{DEVELOPING WEB-BASED TEACHING MATERIALS BASED ON LEARNING STYLES IN PHYSICS}

\author{
Ary Purmadi, Herman Dwi Surjono \\ FIP IKIP Mataram, FT Universitas Negeri Yogyakarta \\ arypurmadi@uny.ac.id, hermansurjono@uny.ac.id
}

\begin{abstract}
This study aims at producing web-based teaching materials based on learning styles, revealing the feasibility of the web-based teaching materials, and revealing the effectiveness of web-based teaching materials for physics of SMAN 1 Sukamulia. It applied the research and development with 3 stages, i.e.: planning, design, and development. The process of validation of this product was carried out through 3 stages, i.e.: alpha testing, beta testing and product testing. The results of this study were that: (1) the web-based teaching materials have five learning feature; (2) the developed product is proper to be used; (3) students learning styles test results show 14 kinestetic learners, 9 visual learners, and 8 auditory learners; (4) there is an increase in students' cognitive learning achievement after using the web-based teaching by $31.87 \%$. The average score of the pretest is 52.03 , and posttest 83.90. The percentage of students' learning mastery is $97 \%$ (30 out of 31 students'), and the result obtained from response of students' after using the media during the teaching process indicates a good category.. From the result above, it can be concluded that teaching by using the web-based teaching materials is effective.
\end{abstract}

Keywords: web-based teaching materials, development, learning styles. 


\section{Pendahuluan}

Pendidikan merupakan salah satu faktor utama dalam menciptakan generasi bangsa yang berwawasan tinggi dan memiliki akhlak yang baik. Hal ini sebagaimana yang menjadi tujuan dari kurikulum 2013 dalam Mendikbud No 69 Tahun 2013 (2013, p.4), yaitu untuk mempersiapkan manusia Indonesia agar memiliki kemampuan hidup sebagai pribadi dan warga negara yang beriman, produktif, kreatif, inovatif, dan afektif serta mampu berkontribusi pada kehidupan bermasyarakat, berbangsa, bernegara, dan peradaban dunia.

Salah satu cara untuk dapat memperoleh pendidikan adalah melalui sekolah sebagai jalur pendidikan formal dengan proses pembelajaran yang telah terstruktur dan bersifat akademis. Melalui sekolah, siswa dapat mengembangkan segala potensi yang dimilikinya dengan dukungan sumber belajar telah disediakan. Pendidikan diselenggarakan dengan memberikan keteladanan, membangun kemauan, mengembangkan kreativitas peserta didik, dan memberdayakan semua komponen layanan pendidikan.

Menciptakan pendidikan yang baik tentunya harus ada acuan yakni kurikulum. Kurikulum memberi gambaran tentang pembelajaran yang harus dilaksanakan di setiap satuan pendidikan tak terkecuali pada tingkatan Sekolah Menengah Atas (SMA). SMA merupakan lembaga pendidikan yang mengemban tugas dari pemerintah sebagai penyelenggara pendidikan. Penyelenggaraan pendidikan pada tingkat SMA dalam kurikulum 2013 banyak terjadi perubahan dan penyempurnaan proses pembelajaran. Proses pembelajaran tidak lagi berpusat pada guru (teacher centered) melainkan berpusat pada siswa (student centered). Selain itu juga, materi pelajaran yang dikembangkan harus disusun dan dilaksanakan berdasarkan karakteristik peserta didik. Penyempurnaan dari proses pembelajaran ini diarahkan untuk meningkatkan kualitas pembelajaran dan inovasi yang ada dalam pembelajaran.
Seiring dengan penyempurnaan proses pembelajaran, peran guru juga tidak lagi sekedar mengajar di kelas namun juga dituntut untuk mengetahui informasi lengkap tentang setiap siswa. Hal ini tentunya untuk memberikan pembelajaran yang terbaik untuk siswa.

Salah satu upaya yang dapat dilakukan untuk menciptakan pembelajaran yang terbaik untuk siswa adalah menggunakan sumber belajar yang bervariasi. Keberadaan sumber belajar akan mempermudah proses pembelajaran dalam pencapaian tujuan pembelajaran. Sumber belajar dapat berupa informasi yang disajikan dalam berbagai jenis media yang dapat membantu siswa dalam meningkatkan hasil belajar yang akan dicapai.

Bahan ajar termasuk bagian dari sumber belajar. Bahan ajar memegang peranan penting untuk membantu siswa mencapai tujuan pembelajaran. Sebagaimana yang dijelaskan oleh Depdiknas (2008, p.2), bahwa bahan ajar merupakan bagian penting dalam pelaksanaan pendidikan di sekolah. Melalui bahan ajar guru akan lebih mudah dalam melaksanakan pembelajaran dan siswa akan terbantu dan mudah dalam belajar. Bahan ajar yang dikembangkan dengan berbagai variasi akan membuat kegiatan pembelajaran menjadi lebih menarik.

Salah satu cara untuk menghasilkan bahan ajar yang menarik adalah menerapkan bahan ajar berbasis web. Bahan ajar berbasis web dikatakan menarik jika siswa merasa nyaman menggunakan bahan ajar web dalam belajar. Selain menarik juga, bahan ajar web dapat memudahkan siswa untuk mengakses berbagai materi pembelajaran karena memuat dua atau lebih konten dalam bentuk teks, gambar, suara, animasi, video, dan lain-lain.

Setiap siswa dalam belajar memiliki kelebihan dan kekurangan dalam memahami materi pelajaran. Kekurangan yang diterima sebagaimana adanya akan berusaha untuk dianalisis dan dipecahkan sementara kelebihan yang dimiliki akan dikelola dan dikembangkan ke arah yang lebih baik 
untuk mendapatkan hasil yang optimal. Sebagaimana yang dikemukakan oleh Ghufron \& Risnawita(2014,p.8), bahwa individu adalah suatu kesatuan yang masing-masing memiliki ciri khasnya, dan karena itu tidak ada dua individu yang sama. Satu sama lainnya berbeda-beda. Ada yang lambat dan ada yang cepat belajarnya. Perbedaan juga terjadi pada gaya belajar individu. Ada individu yang lebih sesuai dengan gaya belajar tertentu dan ada individu yang tidak sesuai dengan gaya belajar tertentu.

Penjelasan di atas memiliki makna bahwa setiap siswa memiliki kemampuan dan cara belajar yang berbeda-beda. Cara yang digunakan dalam belajar disebut juga dengan gaya belajar (learning style). Gaya belajar merupakan cara yang dilakukan oleh siswa dalam menyerap informasi saat kegiatan belajar berlangsung. Sebagaimana yang dikemukan oleh Kolb dalam Hawk \& Shah (2007, p.5),learning style as distinctive and observable behaviors that provide clues about the mediation abilities of individuals and how their minds relate to the world and, therefore, how they learn. Dapat diartikan gaya belajar sebagai perilaku khas dan diamati yang memberikan petunjuk tentang kemampuan individu dan cara seseorang berpikir berhubungan dengan dunianya dan oleh karena itu, cara seharusnya seseorang itu belajar".

Kemampuan dalam menyerap materi pelajaran tentunya berbeda-beda, ada yang cepat, sedang dan sangat lambat. Oleh karena itu perlu digunakan cara yang berbeda pula untuk memahaminya. Menurut Khosiyah (2012, p.74), bahwa perbedaaan gaya belajar itu menunjukkan cara tercepat dan terbaik bagi setiap individu bisa menyerap sebuah informasi dari luar dirinya."

Penyusunan bahan ajar yang sesuai dengan gaya belajar siswa, tentunya untuk meningkatkan hasil belajar. Gaya belajar memiliki hubungan dengan hasil belajar siswa. Pernyataan ini didapatkan dan diperkuat oleh hasil penelitian Margareta (2013, p.1) meneliti tentang hubungan gaya belajar VAK (Visual, Auditory and Kinestetic) dengan prestasi belajar pada matapelajaran biologi di SMPN III Padang. Hasil penelitian menyatakan bahwa terdapat hubungan antara gaya belajar visual, audio dan kinestetik dengan prestasi belajar siswa kelas VIII SMPN 3 Padang Sumatera Barat sebesar $38 \%$ pada mata pelajaran Biologi tahun ajaran 2012/2013.

Jadi semakin seseorang menyadari gaya belajar dan menggunakan cara-cara yang efisien sesuai dengan gaya belajarnya dan memilih bahan ajar yang sesuai maka akan memperoleh prestasi yang lebih baik. Melihat penelitian tersebut, tentunya kondisi yang ideal untuk siswa jika ingin mendapatkan hasil belajar yang memuaskan adalah siswa dapat belajar dengan gaya belajar yang sesuai serta didukung dengan beberapa faktor salah satunya dengan memilih bahan ajar.

Terdapat berbagai macam model gaya belajar yang dikembangkan oleh para ahli untuk mendeteksi gaya belajar seseorang. Namun dari semua model tersebut, model VAK merupakan model gaya belajar yang paling mudah untuk diamati dan dinilai karena model ini dapat dilihat dari indera yang digunakan seseorang ketika belajar. Model VAK membagi gaya belajar siswa menjadi 3 tipe. Ada yang belajar dengan cara melihat (visual learner), ada yang belajar dengan cara mendengar (auditory learner) dan ada juga yang belajar dengan beraktifitas (kinestetic learners). Beragamnya tipe gaya belajar siswa ini tentu menjadi perhatian guru saat mengajar di kelas. Apalagi dalam mengajar materi yang berhubungan dengan hitungan dan pemahaman konsep materi yang mendalam seperti materi Fisika, guru hendaknya harus memahami dengan baik gaya belajar siswa sehingga pemahaman konsep yang diajarkan dapat diterima dengan baik oleh siswa.

Berdasarkan analisis kebutuhan pada saat prasurvei yang dilakukan di SMA Negeri 1 Sukamulia dapat diketahui ada beberapa kendala-kedala yang terjadi dalam proses pembelajaran di sekolah yakni: 
(1) hasil belajar dalam mata pelajaran Fisika masih belum maksimal; (2) sekolah memiliki keterbatasan pada penyediaan sumber belajar yang menyebabkan siswa masih kesulitan dalam mencari materi pelajaran; (3) siswa belum diberikan kebebasan dalam belajar sesuai dengan kebutuhannya menggunakan metode ceramah, tanya jawab, dan presentasi yang dilakukan selama ini didapatkan di kelas; (4) tidak tersedianya bahan ajar yang digunakan guru saat mengajar sehingga sampai saat ini belum bisa mengakomodir gaya belajar siswa menyebabkan siswa kesulitan dalam memahami pelajaran.

Berkaitan dengan berbagai masalah yang ditemukan pada saat prasurvei, peneliti ingin mengembangkan bahan ajar berbasis web berdasarkan gaya belajar siswa pada mata pelajaran Fisika. Pentingnya bahan ajar yang sesuai dengan gaya belajar siswa untuk memberikan kenyamanan siswa dalam belajar. Kenyamanan dalam belajar tentunya akan mempercepat proses pemahaman materi pelajaran yang dipelajari. Untuk mengidentifikasi gaya belajar siswa, peneliti mengadopsi cara Kolb dalam menentukan gaya belajar siswa menggunakan instrumen gaya belajar. Penilaian gaya belajar ini nantinya akan dapat diakses siswa pada produk yang dikembangkan. Setelah mengetahui hasil gaya belajar siswa, produk akan mengarahkan siswa untuk mempelajari bahan ajar yang sesuai tersebut.

Produk yang dikembangkan ini diharapkan mampu meningkatkan hasil belajar siswa pada mata pelajaran Fisika. Bahan Ajar Fisika berbasis web yang dikembangkan didasarkan atas keberagaman gaya belajar siswa saat belajar. Selain itu juga adanya bahan ajar ini diharapkan mampu menjadikan siswa semakin mandiri dalam memahami pelajaran Fisika. Kemudahan belajar secara mandiri tentunya akan memberi dampak positif kepada siswa dalam mengembangkan pengetahuannya. Akses kepada sumber belajar yang sesuai dengan gaya belajar siswa tentunya sangat dibutuhkan siswa ketika guru sepe- nuhnya belum mampu menjelaskan materi di sekolah. Tuntutan dari kurikulum 2013 juga mengharuskan bahwa siswa aktif dalam mencari sumber atau bahan ajar yang telah disediakan baik sifatnya cetak maupun non cetak yang bisa didapat dari internet.

\section{Metode Penelitian}

Jenis penelitan ini adalah penelitian dan pengembangan atau Research and Development (R\&D). Orientasi dari penelitian dan pengembangan ini adalah bahan ajar fisika berbasis web berdasarkan model gaya belajar VAK. Penelitian ini dilaksanakan pada bulan Oktober 2014 sampai April 2015. Bahan ajar fisika berbasis web yang dikembangkan merupakan sumber belajar yang mendukung proses pembelajaran IPA pada kurikulum 2013 mata pelajaran fisika bahasan fluida statis dengan indikator menjelaskan hukum pascal dan archimedes untuk kelas X Jurusan IPA di SMA Negeri 1 Sukamulia.

Model pengembangan dalam produk ini diadaptasi dari Alessi \& Trollip (2001, pp.410-413). Tahapan yang ada dalam model yang dikembangkan sesuai mengikuti prosedur Alessi dan Trollip adalah tahap perencanaan (planning), desain (design) dan pengembangan (development).

Tahap Perencanaan (planning), yang dilakukan dalam tahap ini sebagai berikut. Pertama adalah mendefinisikan ruang lingkup penelitian (define the scope) denganmateri pelajaran fiska SMA kelas $X$ semester genap bahasan fluida statis dengan indikator materi pada hukum pascal dan hukum archimedes. Kompetensi inti (KI) dalam materi fluida statis yaitu pada KI 1-4. Sementara untuk standar kompetensinya yaitu "Menerapkan hukum-hukum pada fluida statik dalam kehidupan sehari-hari".

Kedua, mengidentifikasi karakteristik siswa (identify learner characteristic). Identifikasi yang lebih spesifik terhadap karakteristik siswa SMA Negeri 1 Sukamulia, dilakukan dengan membagikan in- 
strumen dalam rangka analisis kebutuhan ketika prasurvei di sekolah. Ketiga adalah menentukan dan mengumpulkan sumbersumber (determine and collect resources) dari buku, jurnal, artikel, dan internet, sebagai referensi dalam menyusun bahan ajar fisika untuk kelas X SMA. Keempat adalah melakukan brainstorming (conduct initial brainstorming) yaitu melakukan diskusi dengan guru mata pelajaran fisika, dan teman sejawat dalam rangka membuat konsep desain awal e-learning Fisika.

Tahap desain (design), pada tahap ini aktivitas yang dilakukan berhubungan dengan pengaturan isi atau konten yang akan di-upload ke e-learning. Tahap ini terdiri dari langkah-langkah sebagai berikut. Pertama adalah melakukan analisis konsep dan tugas (conduct task and concept analysis) seperti menganalisis pembelajaran, mengadaptasi penilaian gaya belajar yang dibuat oleh Chislet \& Chapman sesuai dengan model VAK, pengumpulan bahan berupa teks, gambar, video, animasi dari berbagai sumber. Kedua adalah membuat struktur program pengembangan bahan ajar fisika berbasis web berupa menyusun desain flowchart. Ketiga adalah endeskripsikan program pendahuluan. Keemapat adalah menentukan software yang akan digunakan dalam pembuatan bahan ajar berbasis web.

Tahap pengembangan (development) Pada tahap ini aktifitas yang dilakukan terdapat enam langkah sebagai berikut. Pertama adalah membangun web dengan domain dan hosting yang telah ditetapkan. Selanjutnya pengembang meng-install moodle versi 2.8.3 secara online pada server tersebut yang nantinya akan dijadikan sebagai tempat menyimpan bahan ajar fisika. Setelah mempunyai web, ada beberapa peran yang akan dikembangkan pada e-learning yaitu sebagai administrator (admin), teacher (guru) dan user (siswa). Peran tersebut untuk dapat mengembangkan e-learning yang sesuai dengan kebutuhan dan karakteristik siswa yang menjadi user. Kedua, menyiapkan teks, video, audio, gambar dan animasi yang akan dijadikan sebagai content. Konten yang akan di-upload dipersiapkan dalam bentuk file doc, pdf, video, animasi dan mp3. Bahan ajar yang dikembangkan disesuaikan, kedalam tiga tipe gaya belajar yaitu bahan ajar untuk pebelajar visual (learning materials for visual learners), bahan ajar untuk pebelajar auditori (learning materials for auditory learners), bahan ajar untuk pebelajar kinestetik (learning materials for kinestetik learners). Bahan ajar fisika ini dikembangkan berdasarkan struktur program yang telah dibuat.

Ketiga, menggabungkan bagian (assemble the pieces) dilakukan dengan menggabungkan teks, audio, video, animasi yang telah diseleksi dan dipersiapkan, untuk bahan ajar fisika berbasis web. Keemapt adalah Menyiapkan materi-materi pendukung (prepare support material). Kelima adalah evaluasi formatif melalui: (a) uji alpha, melibatkan dua orang ahli materi yang menekuni keilmuan fisika dan dua orang ahli media dengan kriteria memiliki kompetensi mengenai pembelajaran berbasis web; (b) uji beta yang melibatkan tiga siswa kelas $X$ IPA 1 dengan tingkat kemampuan tinggi, sedang dan rendah, kemudian dianalisis dan dilakukan revisi akhir. Keenam, evaluasi Sumatif, yakni menggunakan bahan ajar berbasis web dalam proses pembelajaran fisika di laboratorium, pada subjek uji coba seluruh siswa kelas IPA 2 SMAN 1 Sukamulia. Dalam tahap ini dilakukan pengumpulan data tentang respon setelah siswa belajar mata pelajaran fisika melalui lembar angket, menilai hasil belajar melalui pemberian soal pretest dan postest dan melihat penilaian respon siswa selama menggunakan media.

Uji coba pada penelitian ini terdiri dari 3 tahap, yaitu: (1) uji alpha/validasi ahli yang mana hasil validasi akan dijadikan bahan untuk merevisi produk awal; (2) uji beta dilakukan untuk menguji apakah kualitas bahan ajar berbasis web yang dihasilkan telah terpenuhi dari segi layak. Tindakan yang dilakukan adalah dengan meminta penilaian dari 3 orang siswa IPA 1 yang dipilih berdasarkan kemampuan akademik dengan rekomendasi dari guru 
matapelajaran yaitu tinggi, sedang, dan kurang. Siswa tersebut diminta untuk mengerjakan pretest, tes gaya belajar, membuka dan mempelajari paket bahan ajar, dan menjawab postest kemudian diminta memberikan komentar/masukan tentang produk. Berdasarkan masukan tersebut dilakukan revisi terakhir terhadap produk, maka diperoleh produk yang siap digunakan pada uji coba produk. Selama proses pengembangan bahan ajar berbasis web untuk mata pelajaran fiska dilakukan ongoing evaluation.

Subjek uji coba adalah siswa kelas IPA 2 SMAN 1 Sukamulia tahun ajaran 2014/2015 yang berjumlah 31 orang. Uji coba produk dilaksanakan pada bulan April 2015.

Jenis data dalam penelitian ini adalah data kualitatif dan data kuantitatif. Data kualitatif diperoleh dari komentar dan saran para ahli, sedangkan data kuantitatif diperoleh dari hasil validasi oleh ahli materi, ahli media, dan siswa. Data kuantitatif berupa skor, selanjutnya dianalisis dan dikonversikan ke dalam bentuk data kualitatif. Hasil konversi tersebut kemudian menjadi tolak ukur untuk menentukan kelayakan pengembangan bahan ajar berbasis web. Data penilaian hasil belajar diperoleh dari hasil pretest dan posttest berupa data kuantitatif. Sedangkan penilaian respon siswa diperoleh dari data kuantitatif yang dikonversikan menjadi kualitatif. Instrumen atau alat pengumpulan data yang digunakan berupa observasi, wawancara, lembar angket (untuk validasi ahli materi dan ahli media serta lembar angket untuk penilaian atau tanggapan uji coba produk), dokumentasi (nilai hasil belajar fisika tahun ajaran 2013/2014).

Data hasil penelitian ini adalah berupa tanggapan ahli materi, ahli media dan siswa terhadap kualitas produk yang telah dikembangkan ditinjau dari aspek materi dan aspek media. Data berupa komentar, saran, revisi, dan hasil pengamatan peneliti selama proses uji coba dianalisis secara deskriptif kualitatif, dan disimpulkan sebagai masukan untuk memperbaiki atau merevisi produk yang telah dikembangkan.

Sementara, data berupa skor tanggapan ahli materi, ahli media dan siswa yang diperoleh melalui kuesioner, dianalisis secara deskriptif kuantitatif dengan teknik kategorisasi. Langkah-langkah yang digunakan untuk menentukan kriteria kualitas produk yang telah dikembangkan, sebagai berikut. Data yang diperoleh dari kuesioner tentang tanggapan siswa diubah dulu menjadi data interval sebagai berikut: "Sangat Baik"= 5, "Baik = 4, "Cukup" = 3, "Kurang"= 2, "Sangat Kurang" = 1 .

Skor yang diperoleh kemudian dikonversikan menjadi kualitatif skala lima, dengan acuan rumus yang dikutip dari yang dikembangkan Sudijono (2011, pp.329-339) dapat dilihat pada Tabel 1.

Tabel 1. Kriteria Penilaian

\begin{tabular}{cl}
\hline Nilai & \multicolumn{1}{c}{ Skor } \\
\hline A & $X>X_{i}+1,5 \mathrm{Sd}_{i}$ \\
B & $X_{i}+0,5 \mathrm{Sd}_{\mathrm{i}}<X \leq \mathrm{X}_{\mathrm{i}}+1,5 \mathrm{Sd}_{\mathrm{i}}$ \\
C & $X_{\mathrm{i}}-0,5 \mathrm{Sd}_{\mathrm{i}}<X \leq \mathrm{X}_{\mathrm{i}}+0,5 \mathrm{Sd}_{\mathrm{i}}$ \\
D & $X_{\mathrm{i}}-0,5 \mathrm{Sd}_{\mathrm{i}}<\mathrm{X} \leq \mathrm{X}_{\mathrm{i}}-1,5 \mathrm{Sd}_{\mathrm{i}}$ \\
E & $X<\mathrm{X}_{\mathrm{i}}-1,5 \mathrm{Sd}_{\mathrm{i}}$ \\
\hline
\end{tabular}

Ketentuan :

Rerata skor ideal $(X \mathrm{X})=\frac{1}{2}$ (skor maksimal ideal + skor minimal ideal)

Standar Deviasi ideal (Sdi) $=\frac{1}{6}($ skor maksimal ideal - skor minimal ideal)

$\mathrm{X}$ ideal $=$ skor empiris

Tabel 2. Konversi rerata skor Menjadi Kriteria untuk Menilai Kelayakan Produk

\begin{tabular}{ccc}
\hline Nilai & Kriteria & Interval Rerata Skor \\
\hline 5 & Sangat Baik & $4,2<\mathrm{x}$ \\
4 & Baik & $3,4<\mathrm{x}<4,2$ \\
3 & Cukup & $2,6<\mathrm{x} \leq 3,4$ \\
2 & Kurang & $1,8<\mathrm{x} \leq 2,6$ \\
1 & Sangat Kurang & $\mathrm{x} \leq 1,8$ \\
\hline
\end{tabular}

Berdasarkan hasil konversi skor ke nilai maka akan diperoleh nilai produk yang sedang dikembangkan. Untuk mengetahui bahan ajar efektif meningkatkan 
kemampuan kognitif siswa dengan melihat perubahan kemampuan awal siswa dengan membandingkan nilai pretest dan posttest siswa sebelum dan sesudah menggunakan bahan ajar fisika berbasis web yang sesuai dengan gaya belajar. Peneliti juga melihat persentase ketuntasan belajar siswa berdasarkan kriteria ketuntasan minimal di SMA Negeri 1 Sukamulia yang membatasi KKM untuk mata pelajaran fisika minimal "67". Selain itu juga, efektifitas dapat dinilai dari respon siswa selama menggunakan bahan ajar berbasis web dengan minimal mendapat kategori "cukup".

Pada penelitian ini uji tes sumatif dilakukan hanya dengan satu kelas eksperimen tanpa menggunakan kelas kontrol, sehingga untuk menghitung besarnya effect size pada penelitian ini hanya melibat $\mathrm{d}$ (gain). Arikunto (2006, p.277) nilai d diperoleh dari:

$$
E S=d=\overline{X_{2}}-\overline{X_{1}}
$$

Keterangan:

ES : effect size.

$\mathrm{d}$ : gain.

$\overline{X_{2}} \quad$ : nilai rata-rata pretest

$\frac{X_{2}}{X_{1}}$ : nilai rata-rata posttest

\section{Hasil Penelitian dan Pembahasan}

Hasil Pengembangan Bahan Ajar Berbasis Web

Pada tahap perencanaan akan diuraikan empat kegiatan yang dilakukan sebagai berikut. Pertama adalah mendefenisikan ruang lingkup penelitian, yaitu menetapkan kompetensi inti (KI) dan kompetensi dasar yang meliputi: (1) menghayati dan mengamalkan ajaran agama yang dianutnya (2) menghayati dan mengamalkan perilaku jujur, disiplin, tanggung jawab, peduli (gotong royong, kerjasama, toleran, damai), santun, responsif dan proaktif dan menunjukkan sikap sebagai bagian dari solusi atas berbagai permasalahan dalam berinteraksi secara efektif dengan lingkungan sosial dan alam serta dalam menempatkan diri sebagai cerminan bang- sa dalam pergaulan dunia; (3) memahami dan menerapkan pengetahuan faktual, konseptual, prosedural dalam ilmu pengetahuan, teknologi, seni, budaya, dan humaniora dengan wawasan kemanusiaan, kebangsaan, kenegaraan, dan peradaban terkait fenomena dan kejadian, serta menerapkan pengetahuan prosedural pada bidang kajian yang spesifik sesuai dengan bakat dan minatnya untuk memecahkan masalah; (4) mengolah, menalar, dan menyaji dalam ranah konkret dan ranah abstrak terkait dengan pengembangan dari yang dipelajarinya di sekolah secara mandiri, dan mampu menggunakan metoda sesuai kaidah keilmuan. Kompetensi dasar yang dikembangkan dalam mata pelajaran fisika ini adalah menerapkan hukum-hukum pada fluida statik dalam kehidupan seharihari dengan indikator yakni: (1) menjelaskan hukum-hukum fluida statis (2) menerapkan hukum-hukum fluida statis dalam menyelesaikan permasalahan.

Kedua adalah mengidentifikasi karakteristik siswa, karakteristik siswa jurusan IPA SMAN 1 Sukamulia yang sudah mampu menggunakan komputer, dan juga tertarik untuk belajar melalui komputer. Ketiga adalah menentukan dan mengumpulkan sumber belajar yang digunakan, sumber atau referensi yang dijadikan acuan dalam proses pengembangan bahan ajar berbasis web. Referensi dan URL yang dapat dijadikan acuan untuk pengembangan konten paket bahan ajar, baik dalam bentuk teks, gambar, video dan animasi yang diperoleh dari buku dan internet. Keempat, melakukan brainstorming, melakukan diskusi dengan dosen/guru fisika dan temanteman sejawat sebagai expert judgment, mengenai konten yang akan dikembangkan.

Pada tahap desain, peneliti melakukan analisis konsep dan tugas yang berkaitan dengan topik, pembuatan flowchart, pembuatan layout tampilan depan e-learning, pengumpulan sumber-sumber untuk mengisi konten, dan menentukan software yang digunakan; (a) melakukan analisis konsep dan tugas, yaitu dengan menentukan indikator yang ingin dicapai dan 
pembuatan silabus serta RPP; (b) pembuatan flowchart, bertujuan untuk menggambarkan alur untuk meng akses e-learning dan alur untuk masuk ke course materi pelajaran fluida statis. (c) pembuatan halaman pendahuluan yang bertujuan mengenalkan isi dari e-learning (d) software yang digunakan yaitu moodle, dreamweaver dan software online dari allthetest.com.

Produk yang dihasilkan dalam penelitian ini produk bahan ajar berbasis web yang memiliki 5 fitur pembelajaran yakni tes gaya belajar, paket bahan ajar (Visual Auditori dan Kinestetik), forum diskusi, fasilitas chatting, dan tes penilaian (pretest dan postest). Produk yang dikembangkan ini telah melalui rangkaian persiapan dan penggabungan materi yang akan dijadikan konten, serta materi pendukung yang lain seperti contoh soal dan pembahasan, sehingga nantinya produk ini dapat untuk dievaluasi tingkat evaluasi formatif dan sumatif.

\section{Hasil Uji Coba Produk}

Data diperoleh dari tiga kegiatan uji coba yang dilakukan, yaitu dari data uji Alpha, data uji coba beta, dan data hasil uji coba produk. Data uji coba ahli/validasi ahli dilakukan untuk menilai atau menentukan kevalidan bahan ajar berbasis web berdasarkan gaya belajar untuk mata pelajaran fisika yang dihasilkan, serta meminta masukan atau komentar dari beberapa ahli. Data yang diperoleh berupa data kuantitatif, yaitu skor penilaian ahli dan data kualitatif berupa saran atau ma-sukan yang akan digunakan untuk mem-perbaiki produk. Data uji alpha terdiri dari: (1) terdapat dua orang ahli di bidang fisika sebagai ahli materi. Dengan berpedoman hasil konversi rerata skor pada tabel 2, dapat disimpulkan bahwa penilaian dari kedua ahli materi terhadap keseluruhan instrumen diperoleh rerata penilaian sebesar 4,85 dalam kategori sangat baik, oleh karena itu dari sisi materi dinyatakan "layak" diujikan pada tes berikutnya yaitu uji beta; (2) terdapat dua orang ahli e-learning sebagai ahli media. Penilaian dari ahli media terhadap keseluruhan instrumen diperoleh skor sebesar 4,00 dalam kategori baik, oleh karena itu dari sisi media dinyatakan "layak" diujikan pada tes berikutnya yaitu uji beta.

Kemudian data uji coba beta dilakukan dengan melibatkan 3 orang siswa siswa kelas X IPA 1 yang dipilih berdasarkan kemampuan akademik berdasarkan rekomendasi guru mata pelajaran, yaitu tinggi, sedang, dan rendah untuk mencoba dan mengamati produk yang dihasilkan. Skor penilaian berdasarkan data uji beta yang melibatkan tiga orang siswa dengan 15 indikator adalah 187, sehingga rerata hasil penilaian berdasarkan uji beta tersebut adalah 4,15. Mengacu pada tabel konversi, hasil penilaian bahan ajar berbasis web untuk mata pelajaran fisika dari siswa termasuk dalam kategori baik. Pada uji beta ini dilakukan pretest dan posttest untuk mengetahui kemampuan atau hasil belajar dari materi fluida statis dengan menggunakan e-learning serta dilakukan juga penilaian tes gaya belajar untuk mengetahui gaya belajar siswa.

Selanjutnya uji coba produk melibatkan 31 siswa kelas X IPA 2 SMAN 1 Sukamulia. Siswa diminta sebelumnya mengakses e-learning dengan cara membuka menu-menu yang tersedia seperti pretest dan tes gaya belajar, melihat dan mempelajari paket bahan ajar yang sesuai dengan hasil gaya belajar dan mengerjakan postest, yang kemudian siswa diminta tanggapannya dengan cara mengisi kuesioner yang telah diberikan. Jumlah skor penilaian berdasarkan data uji coba program dengan 10 indikator adalah 1285 , sehingga rerata hasil penilaian berdasarkan uji beta tersebut adalah 4,15. Mengacu pada tabel konversi, hasil penilaian bahan ajar berbasis web untuk mata pelajaran fisika dari siswa termasuk dalam kategori baik.

Pada uji coba program dilakukan pretest dan posttest dengan soal pilihan ganda untuk mengetahui kemampuan atau hasil belajar dari materi fluida statis dengan menggunakan bahan ajar berbasis web. 
Analisis Data

Validasi ahli materi dilakukan oleh dua orang dosen ahli materi yang meliputi aspek lingkup pembelajaran dengan 6 aspek penilaian, aspek pendahuluan dengan 4 indikator, penyajian judul dengan 2 indikator, pendalaman materi dengan 5 indikator, dan partipasi siswa dengan 4 indikator, aktivitas tindak lanjut dengan 2 indikator, dan penilaian dengan 2 indikator.Hasil ini menunjukkan bahwa kelayakan materi fluida statis adalah "Sangat Baik", sehingga dapat dilanjutkan ke tahap uji beta dengan terlebih dahulu melakukan revisi awal sesuai yang disarankan.

Untuk memberikan gambaran tentang kualitas dari materi fluida statis berdasarkan penilaian dari kedua ahli materi dapat dilihat pada Gambar 1.

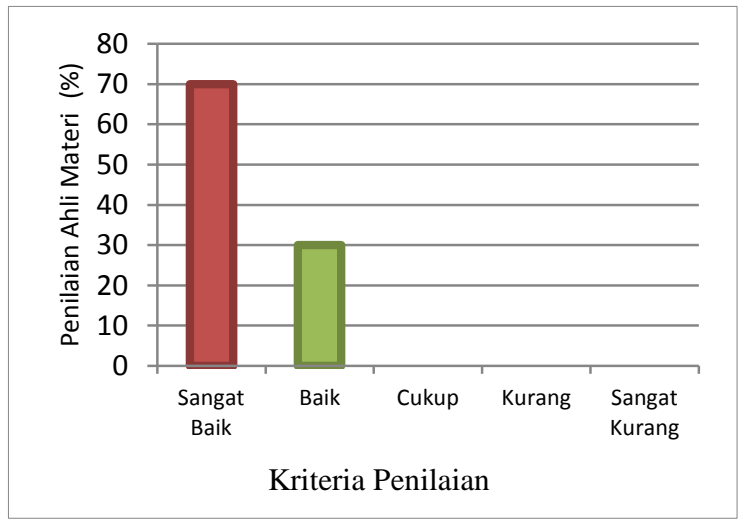

Gambar 1. Grafik Penilaian Kualitas Bahan Ajar BerbasisWeb menurut Ahli Materi

Validasi ahli media dilakukan oleh dua orang dosen ahli media yang meliputi aspek 9 aspek seperti lingkup pembelajaran dengan 3 indikator, informasi tambahan 3 indikator, pertimbangan sikap siswa 1 indikator, hubungan siswa dengan program 6 indikator, navigasi 4 indikator, pedagogi 10 indikator, fitur tak tampak 3 indikator, kehandalan program 3 indikator, dan materi tambahan 2 indikator.Hasil ini menunjukkan bahwa kelayakan bahan ajar berbasis web adalah "Baik", sehingga dapat dilanjutkan ke tahap uji beta dengan terlebih dahulu melakukan revisi awal sesuai yang disarankan.
Untuk memberikan gambaran tentang kualitas dari produk berdasarkan penilaian dari kedua ahli media dapat dilihat pada Gambar 2.

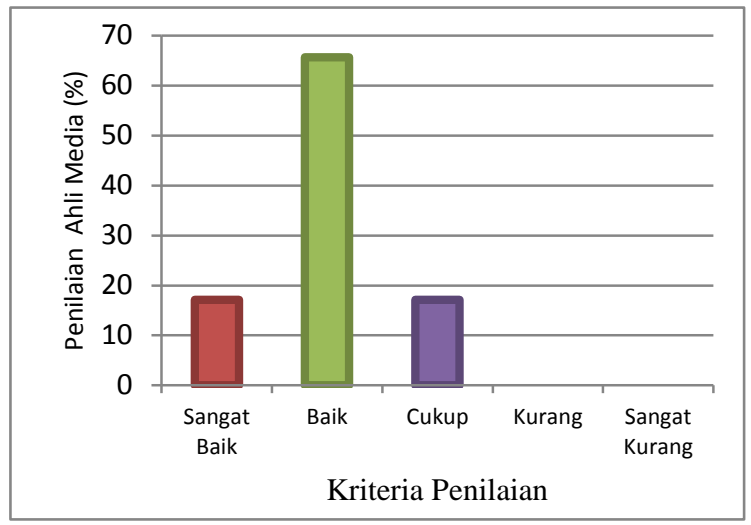

Gambar 2. Grafik Penilaian Kualitas

Bahan Ajar Berbasis Web menurut Ahli Media

Analisis dilakukan berdasarkan data yang diperoleh pada uji coba beta pada siswa. Uji beta dilakukan pada siswa X IPA 1 SMAN 1 Sukamulia sebanyak 3 orang, yaitu 1 orang yang berkemampuan tinggi, 1 orang berkemampuan sedang dan 1 orang berkemampuan rendah. Pemilihan siswa dilakukan langsung oleh guru mata pelajaran. Rerata penilaian dan termasuk kategori "Baik".

Untuk memberikan gambaran tentang kualitas dari produk yang ada dalam bahan ajar berbasis web berdasarkan penilaian dari siswa dapat dilihat pada Gambar 3.

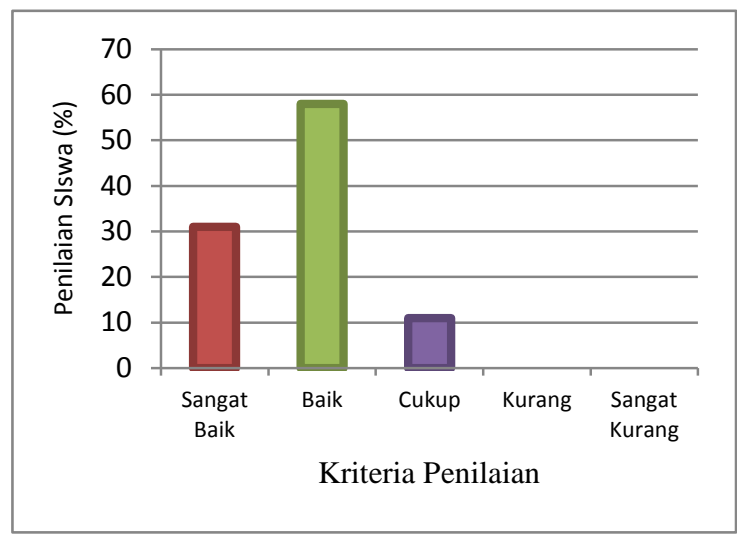

Gambar 3. Grafik Penilaian Kualitas Bahan Ajar Berbasis Web menurut siswa 
Analisis Efektivitas Pembelajaran

Setelah dilakukan evaluasi formatif, maka tahap selanjutnya melakukan evaluasi sumatif dengan uji coba yang melibatkan 31 orang mahasiswa dalam proses pembelajaran sebenarnya. Uji coba ini dimaksudkan untuk mengidentifikasi dan mengetahui kekurangan dari produk bahan ajar berbasis web, dan mengetahui efektivitas dalam pembelajaran. Hasil respon siswa selama menggunakan media dapat diketahui bahwa kualitas e-learning mata pelajaran fisika yang dikembangkan termasuk kriteria "Baik" dengan rerata 4,15 . Untuk memberikan gambaran yang lebih jelas tentang respon siswa dalam menggunakan bahan ajar berbasis web dapat dilihat pada Gambar 4.

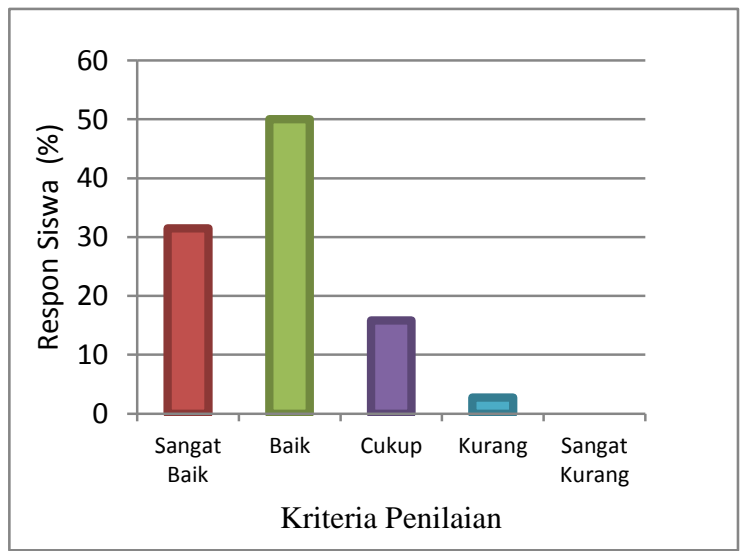

Gambar 4. Grafik Respon Siswa Terhadap Penggunaan Bahan Ajar Berbasis Web

Selain data terkait respon siswa, selanjutnya untuk melihat efektifitas penggunaan bahan ajar berbasis web pada mata pelajaran fisika dalam proses pembelajaran, maka dilakukan tes sumatif dengan memberikan pretest dan posttest pada siswa. Proses yang dilakukan untuk mengukur pencapaian kompetensi siswa secara berkelanjutan dalam proses pembelajaran dan menentukan keberhasilan belajar siswa. Analisis efektivitas hasil belajar pada soal pilihan ganda. Siswa yang mengikuti uji kompetensi dengan perolehan rerata pretest 52,03 dan rerata posttest 83,90. Pretest dilakukan sebagai penjajakan penguasaan materi, sedangkan posttest dilakukan untuk mengetahui peningkatan hasil belajar setelah menggunakan media. Dari data tersebut menunjukkan bahwa pengembangan bahan ajar berbasis web berdasarkan gaya belajar pada mata pelajaran fisika mempunyai efek yang positif untuk digunakan dalam pembelajaran di kelas. Nilai perubahan hasil belajar siswa dari soal pilihan ganda dapat dilihat pada Gambar 5.

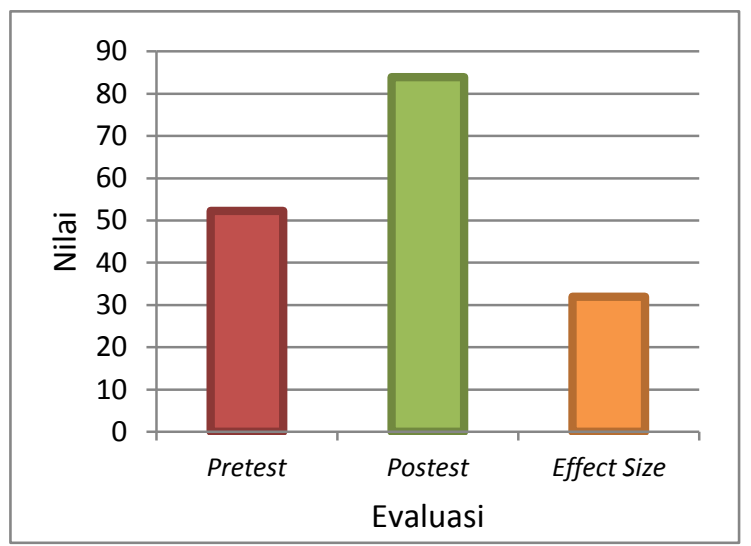

Gambar 5. Grafik Rerata Nilai Hasil Pretest dan Postest

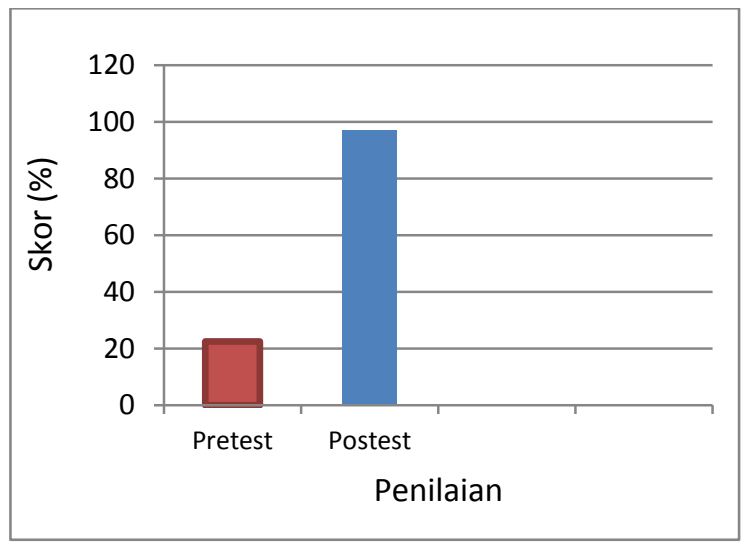

Gambar 6. Grafik Hasil Ketuntasan pretest dan posttest pada Tes Soal Pilihan Ganda

Pencapaian kompetensi seorang siswa dapat dilihat dari keberhasilan siswa tersebut mencapai nilai KKM (Kriteria Ketuntasan Minimal). Untuk KKM Mata Pelajaran Fisika di SMAN 1 Sukamulia pada tahun ajaran 2014/2015 adalah 67 . Siswa dikatakan tuntas jika mencapai nilai $\geq 67$. Sehingga berdasarkan nilai yang didapat bahwa persentase ketuntasan belajar 
siswa pada pretest 22,5\% (7 dari 31) dan posttest $97 \%$ (30 dari 31). Untuk memberikan gambaran lebih jelas tentang ketuntasan hasil belajar siswa yang menggunakan e-learning dapat dilihat pada Gambar 6 .

Gambar 6 menunjukkan terjadi kenaikan yang signifikan terhadap hasil belajar. Dengan demikian ditinjau dari segi efektivitasnya baik dari respon siswa dan nilai hasil belajar maka pengembangan bahan ajar berbasis web pada mata pelajaran fisika dihasilkan telah efektif.

\section{Analisis Gaya Belajar Siswa}

Dari data tes gaya belajar yang didapat oleh siswa pada saat pembelajaran, sebagian besar siswa di kelas tergolong pebelajar kinestetik yakni 14 orang, 9 orang visual dan 8 orang auditori. Hasil tes gaya belajar siswa yang ada pada saat pembelajaran, dapat dijelaskan bahwa adanya keberagaman tentang gaya belajar siswa yang terdapat pada kelas X IPA 2. Gam-baran terkait hasil tes gaya belajar siswa dapat dilihat pada Gambar 7.

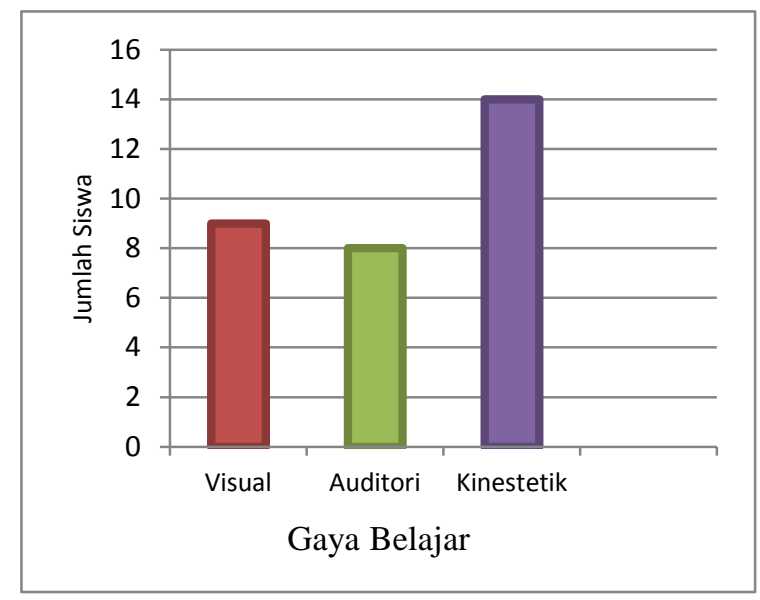

Gambar 7. Hasil Tes Gaya Belajar

Dengan data diatas siswa akan lebih mudah memilih bahan ajar yang sesuai dengan gaya belajarnya serta guru juga dapat memilah siswa yang memiliki gaya belajar tersebut untuk diberikan bahan ajar yang sesuai dan perlakuan pada proses pembelajaran sehingga mempermudah transfer pemahaman materi pelajaran.
Kajian Produk Akhir

Pengembangan bahan ajar berbasis web berdasarkan gaya belajar dilakukan sejak bulan Oktober 2014 sampai April 2015 di SMAN 1 Sukamulia Lombok Timur. Pengembangan bahan ajar berbasis web ini berupa portal e-learning dengan menggunakan LMS Moodle. Moodle merupakan perangkat lunak open source yang mendukung implementasi e-learning dengan paradigma terpadu dimana berbagai fitur penunjang pembelajaran dengan mudah dapat diakomodasi dalam suatu portal e-learning seperti upload/download materi pelajaran, penilaian, diskusi online, chatting, dll.

Bahan ajar ini dikembangkan dengan memanfaatkan salah satu webhosting berbayar dengan menyediakan fasilitas instalasi moodle secara online yaitu idwebhost (http://idwebhost.com). Selain itu juga, dalam pengembangan tes gaya belajar online yang akan diletakkan pada portal e-learning, peneliti memanfaatkan situs pembuat tes kepribadian gratis yaitu allthetest (http://www.allthetest.com). Penyediaan tes gaya belajar ini akan bertujuan agar siswa semakin mengetahui gaya belajarnya sendiri. Portal e-learning yang diberi identitas Bahan ajar berbasis web dapat diakses oleh siswa melalui internet atau online dimana dan kapan saja (any time and any where) dengan nama domain atau URL http:// kelasonlinesman1sukamulia.web.id.

Bahan ajar yang di-upload sebagai konten adalah materi pelajaran kelas $\mathrm{X}$ SMA semester genap dengan Kompetensi Inti 1-4, Kompetensi Dasar 3.7 dengan 2 indikator. Materi yang diambil adalah fluida statis mengenai hukum-hukum fluida statis. Bahan ajar berbasis web ini telah selesai divalidasi oleh 4 validator dengan rincian 2 validator ahli materi dan 2 validator ahli media, serta telah mengikuti tahaptahap dalam pengembangan.

Setelah melalui uji alpha, yakni pada saat validasi media dan materi kemudian dilakukan revisi sesuai saran dan rekomendasi yang diberikan. Hasil evaluasi ahli materi bahan ajar berbasis web yakni 
layak untuk diujicobakan dengan rerata skor 4,85 kategori sangat baik, sedangkan evaluasi oleh ahli media diperoleh rerata skor 4,00 dengan kategori baik. Dengan demikian bahan ajar berbasis web siap untuk diimplementasikan pada tahap berikutnya. Setelah uji alpha, tahap berikutnya adalah uji coba ke lapangan melalui 2 tahapan yaitu tahap uji beta dan uji coba produk dengan mengimplementasikan proses pembelajaran yang sebenarnya.

Hasil analisis data pada saat uji coba beta menunjukkan bahwa penelitian terhadap produk bahan ajar berbasis web berdasarkan gaya belajar pada aspek materi dan media dari siswa mencapai skor 4,15 dengan kategori baik. Produk media pembelajaran ini sudah layak untuk dipergunakan dan disebarluaskan kepada pengguna.

Selanjutnya dilakukan uji coba pada proses pembelajaran yang melibatkan 31 orang siswa pada kelas X IPA 2. Hasil penilaian respon siswa setelah menggunakan bahan ajar berbasis web diperoleh skor 4,15 dengan kategori baik. Peningkatan kemampuan kognitif siswa setelah menggunakan bahan ajar berbasis web meningkat sebesar 31,87 \%. Dari hasil penelitian ini dapat dijelaskan bahwa bahan ajar berbasis web yang disusun berdasarkan gaya belajar siswa efektif untuk pembelajaran di kelas.

Penyusunan bahan ajar sesuai dengan gaya belajar sangat penting untuk memberikan keleluasaan siswa dalam belajar. Hal ini juga diperkuat dengan hasil penelitian oleh Franzoni \& Assar (2009, p.28) tentang penyesuaian gaya belajar, pemilihan strategi mengajar dan media elektronik (e-learning) dapat membantu memfasilitasi proses pembelajaran dan personalisasi sumber daya pedagogis. Dari hasil penelitian ini dapat dijelaskan bahwa peran guru sangat penting dalam memilih strategi mengajar, media dan menyesuaikan gaya belajar siswa berperan dalam memberikan dampak positif untuk proses pembelajaran. Selain itu juga hasil penelitian dari Tanta (2010, p.20), menunjukkan bahwa terdapat pengaruh antara gaya belajar terhadap hasil belajar sebesar $73 \%$ karena kecenderungan kepuasan sebagian besar mahasiswa diukur dari kelulusan pada mata kuliah dari pada pemahaman terhadap isi mata kuliah. Dari hasil penelitian ini dapat dijelaskan bahwa gaya belajar memiliki dampak terhadap hasil belajar mahasiswa. Untuk itu untuk mendapat hasil yang baik identifikasi gaya belajar sangat dibutuhkan oleh pendidik dalam menentukan strategi pembelajaran yang akan digunakan.

Pada saat penelitian, siswa hanya membutuhkan waktu sekitar 30 menit untuk login, menjawab pretest dan tes gaya belajar pada tanggal 8 April 2015. Kemudian hari berikutnya siswa mengakses Bahan ajar berbasis web sesuai dengan hasil gaya belajar tersebut. Hambatan teknis pada saat penelitian yaitu ada beberapa komputer yang belum terinstall program Flash Player dan adobe reader sehingga siswa tidak bisa mengakses tes gaya belajar, video dan materi dalam bentuk pdf. Sehingga peneliti dengan cepat menyelesaikan masalah tersebut dengan menginstal komputer tersebut sehingga siswa dapat mengaksesnya.

Sebagai produk hasil pengembangan, Bahan ajar berbasis web ini tentunya memiliki kelebihan dan kekurangan. Kelebihannya adalah (1) bahan ajar berbasis web ini dapat diakses kapan saja dan dimana saja asalkan siswa telah terdaftar sebagai pengguna, (2) materi yang disajikan disesuaikan dengan gaya belajar siswa sehingga akan lebih dimudahkan dalam memahami materi tersebut. Selain itu juga, (3) komunikasi antara guru dan siswa tidak hanya terjadi di sekolah, (4) update data lebih mudah, (5) sistem penilaian yang lebih praktis dan transparan. (6) Siswa juga dapat memperkaya materi-materi tambahan yang di-linkkan di bahan ajar berbasis web. (7) Selanjutnya siswa dapat belajar secara mandiri dengan tertib dan tidak menimbulkan keributan sehingga pemanfaatan waku belajar bisa lebih optimal. (8) Dengan adanya bahan ajar berbasis web siswa tidak tergan- 
tung lagi dengan bahan ajar yang siftanya cetak semisal buku paket. (9) Materi yang disajikan pada bahan ajar berbasis web juga lebih bervariasi sehingga mudah untuk dipahami.

Sementara kekurangannya sendiri yang berkaitan dengan masalah teknis yakni (1) sering terjadi mati listrik, intenet lambat, beberapa komputer rusak yang menyebabkan siswa tidak bisa mengakses bahan ajar, (2) masalah yang terjadi pada proses pembelajaran yaitu sistem penilaian online yang sangat rawan dengan jawaban siswa yang dapat diduga dapat dikerjakan secara bersama-sama. (3) Kemudian dengan adanya pembelajaran menggunakan web menyebabkan siswa dapat membuka link yang tidak berkaitan dengan materi pelajaran.

Respon positif siswa merupakan bentuk kepuasan tersendiri bagi peneliti, karena produk yang dikembangkan dapat diterima dengan baik oleh guru dan siswa. Artinya pengembangan bahan ajar berbasis web berdasarkan gaya belajar siswa ini telah sesuai target dan layak untuk digunakan. Ketertarikan siswa terhadap sumber belajar merupakan respon yang baik untuk meningkatkan motivasi siswa dan hasil belajarnya. Keberhasilan proses pembelajaran dapat dipengaruhi oleh beberapa faktor salah satunya kesesuaian karakteristik siswa (gaya belajar) dengan bahan ajar yang digunakan. Sebagai guru juga sangat penting sekali untuk memperhatikan bahan ajar yang digunakan untuk proses belajar mengajar dengan melihat kondisi yang ada di sekolah baik sarana prasarana yang disediakan dan kemampuan dalam membuat bahan ajar yang menarik siswa untuk lebih giat belajar sehingga nantinya dapat meningkatkan hasil belajarnya. Bahan ajar berbasis web tentu saja dapat melengkapi proses pembelajaran di kelas dengan standar prosesnya berbasis ICT sesuai dengan tuntutan Kurikulum (K13). Pembelajaran berbasis web dapat menjadi potensi besar untuk meningkatkan pembelajaran di kelas. Sebagaimana yang dikemukakan oleh dari Hadjerrouit (2010, pp.131-132),yakni penggunaan sumber belajar pembelajaran berbasis web di lingkungan sekolah dan penggunaan bahan ajar merupakan bidang yang potensial. Pembelajaran berbasis web akan terus berkembang dan menyediakan pengalaman yang lebih luas bagi guru dan peserta didik serta pembelajaran yang menarik yang tidak mungkin ditemukan pada pembelajaran di kelas tradisional.

Disamping kelebihan tersebut, kekurangan media ini juga terdapat pada terbatasnya materi yang dikembangkan yang sesuai dengan gaya belajar siswa sehingga nantinya guru bisa menambah materi yang cocok untuk siswa tersebut pada materi yang lain. E-learning sangat cocok untuk pembelajaran pada K13 karena pada kenyataannya kurikulum 2013 (K13) terpusat pada siswa (student centered) namun penyajian materi kepada siswa dengan media ini tdak cukup hanya dilepas begitu saja kepada siswa secara mandiri. Guru bisa melakukan penjelasan untuk membantu mempercepat proses pemahaman siswa. Guru sebaiknya dapat memantau dan memandu siswa selama pembelajaran berlangsung, agar siswa tidak membuka situssitus lainnya.

Bahan ajar berbasis web dibuat dan dirancang serta dikembangkan bertujuan sebagai alat bantu guru dalam proses pembelajaran sehingga menciptakan pembelajaran yang kreatif, inovatif, kondusif dan sesuai dengan gaya belajar siswa. Sedangkan untuk siswa media ini dapat digunakan untuk belajar secara mandiri sehingga mengurangi ketergantungan pada bahan cetak yang harganya relatif mahal. Hal ini didukung oleh pernyataan Srivastava \& Agarwal (2013, p.797), bahwa “...menggunakan e-learning yang menarik, menghemat uang, dan pembelajaran yang menyenangkan. Oleh karena itu, pembelajaran e-learning tentunya perlu diimplementasikan dan dikombinasikan dengan pembelajaran konvensional (blended learning) untuk meningkatkan kualitas pembelajaran saat ini. 


\section{Simpulan dan Saran}

Simpulan

Berdasarkan hasil analisis data dan pembahasan dapat disimpulkan hasil pengembangan bahan ajar berbasis web memiliki 5 fitur pembelajaran seperti tes gaya belajar, paket bahan ajar (Visual, Auditori, dan Kinestetik), forum diskusi, fasilitas chatting, tes penilaian (pretest dan postest) yang dikhususkan untuk mata pelajaran Fisika materi Fluida Statis (Hukum Pascal dan Archimedes) kelas X SMA. Kualitas kelayakan bahan ajar berbasis web berdasarkan gaya belajar menurut validasi oleh ahli media termasuk kategori baik, validasi oleh ahli materi termasuk kategori sangat baik. Tanggapan oleh siswa dalam uji beta dalam kategori baik. Berdasarkan penilaian tersebut maka bahan ajar berbasis web berdasarkan gaya belajar siswa yang dikembangkan tersebut layak untuk digunakan pada siswa kelas $X$ di SMAN 1 Sukamulia. Adapun hasil gaya belajar siswa yang didapat pada penelitian ini adalah 14 pebelajar kinestetik, 9 pebelajar visual, dan 8 orang pebelajar auditori. Hasil gaya belajar ini tentunya sangat berperan dalam mengubah paradigma guru dalam membuat berbagai macam bahan ajar untuk mengakomodasi keberanekaragaman gaya belajar siswa seperti bahan ajar berbentuk visual, auditori, dan kinestetik.

Efektivitas pembelajaran menggunakan bahan ajar berbasis web berupa penilaian respon siswa terkait penggunaan media pada saat pembelajaran menunjukkan kategori baik. Sementara dari hasil belajar siswa berupa pretest dan postest terdapat peningkatan pencapaian hasil belajar siswa setelah belajar dengan menggunakan bahan ajar berbasis web sebesar 31,87 \%. Nilai rata-rata pretest 52,03, kemudian pada saat postest 83,90. Presentase ketuntasan belajar siswa pada postest $97 \%$ (30 dari 31 siswa). Dari hasil tersebut dapat diketahui bahwa bahan ajar berbasis web berdasarkan gaya belajar siswa sudah efektif digunakan untuk pembelajaran.
Saran

Saran pemanfaatan produk yang dikembangkan adalah sebagai berikut: (1) Bahan ajar berbasis web ini sesuai dengan desain pembelajaran dan silabus mata pelajaran fisika, serta RPP yang sudah melalui validasi ahli media dan materi, maupun uji coba kepada siswa, maka pemanfaatan media ini dapat diimplementasikan oleh guru pada setiap pelajaran fisika. (2) Guru diharapkan mampu memanfaatkan bahan ajar berbasis web dengan baik agar dapat digunakan untuk kegiatan belajar mengajar dan meningkatkan hasil belajar siswa. (3) Guru dapat memanfaatkan hasil tes gaya belajar siswa untuk memberikan solusi terbaik dalam memahami materi pelajaran yakni memberikan media yang sesuai dengan gaya belajar siswa dan memberikan perlakuan yang sesuai dengan karakteristik gaya belajarnya tersebut sehingga proses transfer pemahaman materi pelajaran lebih cepat dari sebelumnya.

\section{Daftar Pustaka}

Alessi, S.M., \& Trollip, S.R. (2001). Multimedia for learning methods and development (3 rd Ed). Massachusetts: Allyn \& Bacon.

Arikunto, S. (2006). Prosedur penelitian suatu pendekatan praktik, ed revisiVI. Penerbit PT Rineka Cipta: Jakarta.

Depdiknas. (2008). Panduan pengembahan bahan ajar dan media. Jakarta: Direktorat Jenderal Manajemen Pendidikan Dasar dan Menengah.

Franzoni, A.L., \& Assar, S. (2009). Student learning styles adaptation method based on teaching strategies and electronic media. Educational Technology \& Society, 12 (4), 15-29.

Ghufron, M. N. \& Risnawita, R. (2014). Gaya belajar. Yogyakarta: Ar-ruz Media.

Hadjerrouit, Said.(2010). Developing webbased learning resources in school education: a user-centered 
approach. Interdisciplinary Journal of E-Learning and Learning Objects. Vol. 6.115-135.

Hawk \& Shah. (2007). Using learning style instruments to enhance student learning.Decision Sciences Journal of Innovative Education.5(1).1-19.

Khosiyah. (2012). Pengaruh strategi pembelajaran dan gaya belajar terhadap hasil belajar pendidikan agama islam siswa SD INTI NO. 060873 MEDAN. Jurnal Tabularasa PPS Unimed, Vol. 9 No.1.63-80.

Margareta, H. (2012). Hubungan gaya belajar (visual, audio dan kinestetik) dengan prestasi belajar siswa kelas viii smpn 3 padang sumatera baratpada mata pelajaran biologi tahun ajaran 2012/2013. Skripsi. Tidak Dipublikasikan. Universitas Bung Hatta
Mendikbud. (2013). Peraturan Menteri Pendidikan dan Kebudayaan Nomor 69 Tahun 2013 tentang Kerangka Dasar dan Struktur Kurikulum Sekolah Menengah Atas/Madrasah Aliyah.

Sudijono. (2011). Pengantar evaluasi pendidikan. Jakarta: PT Raja Grafindo Persada.

Srivastava, E. \& Agarwal, N. (2013).Elearning: new trend in education and training. International Journal of Advanced Research, Volume 1, Issue 8, 797-810.

Tanta. (2010). Pengaruh gaya belajar terhadap hasil belajar mahasiswa pada mata kuliah biologi umum program studi pendidikan biologi universitas cenderawasih. Jurnal Kependidikan Dasar, Vol 1 (1), 7-21. 